\title{
A Systematic Literature Review on Critical Thinking in an Undergraduate Accounting Programme
}

\author{
Lilian Ifunanya Nwosu ${ }^{1} \&$ Hester Vorster ${ }^{1}$ \\ ${ }^{1}$ School of Accounting Science, North West University, South Africa \\ Correspondence: Lilian Nwosu, School of Accounting Science, North West University, South Africa.
}

Received: August 18, 2020

Accepted: October 12, 2020

Online Published: May 21, 2021

doi:10.5430/ijfr.v12n4p225

URL: https://doi.org/10.5430/ijfr.v12n4p225

\begin{abstract}
The ability of accountancy students to apply critical thinking in solving problems related to modules offered in accountancy undergraduate programme, has remained a concern for many higher institutions. Accountancy students tend to struggle to apply critical thinking to their course work offered in the programme. To be able to apply critical thinking, accountancy students in undergraduate programmes should be able to apply a series of attributes that can enable them to understand questions asked in case study questions or multiple tasks. This study reviewed various ways in which students can apply critical thinking in an undergraduate accounting programme. A systematic literature review was conducted to examine the challenges undergraduate accounting students in South Africa face in applying critical thinking. This study found some of the barriers for applying critical thinking include redundancy, backwardness, application, extent to which preferences are associated to learning, and the ability to engage in real life accountancy practice. Literature reveals that accounting students can use the cube method which includes six steps: describe, compare, associate, analyse, apply, and argue to address the challenges of applying critical thinking. The study however, proposed some strategies that academics can use to ensure that accountancy students are able to apply critical thinking in solving accounting problems. Students are able to apply critical thinking in problem solving. Suggestions for future research were provided.
\end{abstract}

Keywords: accounting, critical thinking, Piaget theory, activity theory, philosophical approach, education approach

\section{Introduction}

Globally, graduates' lack of critical thinking is worrisome for national and international education systems and educators. In U.S colleges, for example, graduates cannot confidently solve problems and think critically (Quitadamo \& Kurtz 2007). Critical thinking assists students both in their academic and personal lives to tackle challenging problems. There is a global call for educators to train graduates to think critically and accountancy undergraduate students are not exempted from this. The ability to be a critical thinker means one is self-disciplined, self-directed, self-organised, self-motivated, self-monitored and self-corrected (Cascini \& Rich 2007). These attributes are essential for students to have, especially when it comes to accountancy students.

Accountancy students are required to acquire critical thinking skills which will assist them in solving complex problems in the modules offered in their programmes. By nature, accounting or an accountancy module is one of the most challenging or complex subjects for many students to learn (Ali et al. 2019). A student in an accountancy programme is expected to take modules such as financial management, taxation, management accounting, auditing, and financial accounting. It follows then that students should be able to apply critical thinking in solving any questions posed in such modules. This paper aims to address the extent to which accountancy students apply critical thinking in problem solving in accountancy undergraduate programmes, the challenges facing accountancy students in applying critical thinking, the strategies used by lecturers to impact students' critical thinking in addressing accounting problems, and the ways in which accountancy students can apply critical thinking in solving problems in undergraduate programmes.

\section{Background}

For decades now, academic institutions have been asked to equip accounting graduates with the kinds of skills and attributes to be problem solving professionals in the ever-changing business world. Critical thinking is on top of the list of skills needed (Sin et al. 2015). Academic institutions are mandated to provide students with the ability to think 
critically towards solving complex problems (Willingham 2008). Implementing the benefits of critical thinking into effective use depends on the level of understanding of academic institutions about the importance of critical thinking for students, academic institutions, employers, and society at large. It is widely understood that critical thinking enables students to be job-ready in addressing complex client issues and having the ability to make informed decisions using higher-order thinking skills. Logical, analytical, reasoning, and decision-making thinking skills of humans help them make judgement calls and improve existing systems of thinking and ways of doing things. Critical thinking improves processes, which in return would assist students to be logically sound in solving complex accounting questions. The potential of critical thinking empowers students to think outside the box in solving critical or complex problems.

As a way forward, Willingham (2008) proposed that critical thinking is not an everyday kind of thinking, and a kind of thinking that anyone can possess, if trained. Critical thinking is essential both for students as well as future employers. The ability of accountancy students to apply critical thinking principles in their daily and future professional lives will depend on their willingness to understand complex questions in different subjects offered in an accountancy programme. They must address these questions and take advantage of these skills to make their profession easy and fun.

The importance of critical thinking in solving complex accounting problems makes this literature study worthwhile. The literature study will seek to answer the following question:

What strategies can be used by the lecturers to ensure that accountancy students are able to apply critical thinking in solving accounting problems?

\section{Methodology}

Paré \& Kitsiou (2017) mentioned six steps when doing a literature review, namely formulating research question and objective, searching existing literature, screening for inclusion, assessing the quality of primary studies, extracting data, and analyzing data. They pointed out that there are different types of literature reviews, for example, narrative, descriptive or mapping, scoping, forms of aggregative, realist, critical reviews, and systematic literature reviews.

Okoli \& Schabram (2010) distinguished three general kinds of literature reviews: theoretical background (brings research question into focus), thesis literature review (allows graduates to discuss existing papers covering the topic under investigation) and stand-alone literature reviews (no primary data is collected and analyzed). This stand-alone literature review is called a systematic literature review. It reviews existing literature papers related to the topic by searching and analyzing academic articles and papers. Based on the, this study is categorized as a systematic literature review study.

This study employed an integrated systematic literature review. Literature that addressed the key elements of the concept were looked at in multiple database searches, including Ebsco Host, Emerald, Eric, Elsevier, Google Scholar, and journals. The literature review allowed the researcher to collect and critically review all related research in the particular field of study. The relevant literature that addresses critical thinking and accountancy students will be reviewed with the aim to formulate a contribution on how accountancy students can apply critical thinking in their studies. In conducting a systematic literature review for this study, the researcher identified the research objectives for the study, searched for relevant studies that addressed the research objectives for this study, extracted information from the studies found, checked for bias and risks related to the extracted information, and paraphrased the information to suit the objectives of the study (Piper 2013).

\section{Literature Review}

The literature review for this study started with an overview of critical thinking, concepts of critical thing, necessity of critical thinking, and the models and theories of critical thinking.

\subsection{The Overview of Critical Thinking}

Critical thinking is not a new concept. Critical thinking can simply be seen as the ability to analyze, evaluate and make conclusions about problems. According to Bers (2005), critical thinking is being treated differently in curricula because there is no single accepted definition. Kurfiss (1988) defined critical thinking as "an investigation whose purpose is to explore a situation, phenomenon, question, or problem to arrive at a hypothesis or conclusion about it that integrates all available information and that can therefore convincingly be justified". Mulnix (2012) claimed that critical thinking uses reason to form our beliefs and that it is not the same as creative or emotional-based thinking. Taylor (2004) gave a more straightforward definition: "Critical thinking is the kind of thinking that professionals in 
the discipline use when doing the work of the discipline". It can be deduced that people get things done in an accurate way by applying critical thinking. The concepts of critical thinking therefore need to be emphasised.

Critical thinking can also be regarded as a deeper thinking, "reasoning, judgment, procedural knowledge, meta-cognition, reflection, questioning and justification" (Wilkin 2017). While Rodzalan and Saat (2015) attested that critical thinking in general involves the skills to investigate a problem and decide on the importance of the content as well as interpret it in addressing a situation. These components of critical thinking should be inculcated in accountancy students for them to be able to solve different problems associated with a given subject. Critical thinking can make students purposeful and goal-oriented and directed. According to Saputra et al. (2018) and Fahim and Eslamdoost (2014), critical thinking is ranked at the top on the list of skills for the $21^{\text {st }}$ century, but many are still confused about the fundamental meaning and importance of critical thinking (Quitadamo \& Kurtz 2007). Critical thinking builds the relationship between how lecturers teach and how students acquire knowledge (Lunenburg 2012). Skills are very important for anyone to compete in this century because it empowers people and improves the quality of lives and society in general. Critical thinking can be defined in numerous ways. Lander and CCEA (2007) described critical not as opposing or impartial, but as "careful and detailed calculation and conclusion." Critical thinking is an affirmative capability for the individuals who have it.

\subsection{The Concept of Critical Thinking in Accounting}

Critical thinking is essential success factor in an academic learning environment. Critical thinking enables problem identification, evaluation, reasoning, and analysis. The process of applying critical thinking can be challenging, but achievable. Students need critical thinking in their academic journey and professional life. However, according to Young and Warren (2011), the application of critical thinking to accounting modules or courses is very difficult. Accounting professionals believe that critical thinking is essential for students to succeed in accounting.

Jenkins (1998) expressed that "Critical thinking is widely regarded by the accounting profession as an intellectual skill that enhances an accountant's ability to analyze and solve nondeterministic problems, detect errors and irregularities, and reach sound judgments". Kimmel (1994) stated that for students to master problems they experience in practice; they need courses that develop their thinking skills. According to Nentl and Zietlow (2008), accountancy students can recognize concepts and sometimes even apply concepts of data, but they can almost never compare, consolidate and evaluate data. Students seem to want to acquire just enough knowledge to pass. Most researchers agree that they rely merely on memorization and reproduction of material and do not seek the meaning behind what is learned.

Critical thinking involves "high-order thinking skills" that every student should be trained in to be able to analyse, communicate, and interact with others. Thompson and Washington (2015) attest that critical thinking in some difficult and more practical subjects involves accessing, analysing, understanding, conceptualisation, and reasoning. These four critical thinking principles are applied by accountancy students to progress in their discipline. Critical thinking focuses on defining problems and finding solutions. It responds to questions for which there are no definite answers, and for which tangible information may be unavailable. It involves the discovery of circumstances that help develop optimal and reasonable suggestions or decision processes. A critical thinking approach is much different from other ways of thinking. Humans minds are always engaged with numerous ideas, and lecturers always have to think in diverse ways, especially in their dealings with students. Daydreaming is another type of thinking whereby the person is distracted, and remembering is also a type of thinking where the individual is concentrating but unproductive. It is a simple way of retrieving information. However, critical thinking is focused, goal-oriented and creative, it is an active procedure fixed in a series of potentials that add up to a cautious attitude that takes nothing for granted.

Just as good writing requires comprehensive rewriting, critical thinking requires rethinking or exceeding the clear and stress-free means (Lander \& CCEA 2007). The general drive of critical thinking is to comprehend but its aim drives further than the purpose, and it almost always leads to assessment and then to conclusion. Critical thinking can simply be said to be a process of understanding how thinking and learning operates, using progressive, directive skills to understand subjects, and examine, manufacture, and evaluate those concepts logically. In critical thinking, skills can be learned, a person can become skilled, and they can use the skills they have learned. It can be said to be the examination of ideas, inferences, assumptions, principles, arguments, conclusions, issues, statements, beliefs, and actions (Firdaus et al. 2015). Both cognitive skills and dispositions come into play with critical thinking, and these dispositions can be methods or practises of the mind, which includes open and fair-mindedness, inquisitiveness, flexibility, a tendency to search for reasons, an ambition to be well-informed, and admiration for and readiness to entertain diverse views (Lai 2011). Accounting as an academic course can involve critical analysis of real-life 
problems or issues and the critical application of skills to resolve the recognised challenges. Accountancy students are allowed to solve real-life problems or challenges with real-life processes and steps. It follows then that in an accountancy programme, a student is expected to employ critical thinking to be able to tackle different tasks. This will enable the student to address complex problems and have the right answers to the problems identified in a given question.

\subsection{The Need for Critical Thinking}

The accounting profession is no longer a clerical task merely involving checking inventory, the manual preparation of receipts or client's requests, confirmation of clients, receivable account balances and many more. Accounting professionals are required to add value in their reading, observation, writing and evaluation (Reinstein \& Bayou 1997). The accounting profession demands some skills that will allow professionals to think outside the box in adding value to clients' needs and expectations in providing efficiency to an organisation. Critical thinking enables an understanding of the process of thinking and learning, and the use of higher-order skills to address complex issues for better comprehension and analysis of issues logically (Reinstein \& Bayou 1997). In higher-order learning, problem analysis, breaking down components into smaller parts, synthesis and critical assessments are performed. The principle of critical thinking is used in addressing complex issues in academic environments as in the case of accountancy or accounting. Critical thinking and its skills assist especially accountancy students to compete locally and globally (Cascini \& Rich 2007). The need for critical thinking in accounting depends on the complexity of the programme. Presently, employers seek to have graduates who have the ability to think borderless (outside the box) (Rodzalan \& Saat, 2018).

Accountancy students are confronted with difficult problems that require them to analyse, observe, evaluate, read, write, interpret to counsel, and make references and recommendations for decision-making. Critical thinking skills are important because it supports students to deal competently with social, scientific, and practical problems (Snyder \& Snyder 2008). Reinstein and Bayou (1997) believe that critical thinking is a procedure that empowers students to understand, add value, and communicate results to other stakeholders. Students with the ability to think critically can solve problems effectively in the case of accounting programmes. Just possessing the knowledge alone is not enough for accounting programmes. Accounting educators must begin to teach students critical thinking skills and other kinds of skills to change the ways of the past and meet future employers' needs (Reinstein \& Bayou 1997). The 21st century accountancy students are expected to have intellectual, quantitative, analytical, communicating, writing, reading, interpretative, and observing skills.

The application of critical thinking in an accounting discipline can be made possible through the use of approaches like philosophy and education. The literature on critical thinking is rooted in two primary academic disciplines, namely philosophy and psychology (Lai 2011).

Lai (2011) has noted a third critical thinking strand also within the field of education. These different academic strands have established various methods to define critical thinking that duplicate their individual concerns. Based on the nature of accounting programmes, critical thinking skills are necessary for a student to succeed, as it enables a student to arrive at a decisive conclusion in a given task (Reinstein \& Bayou 1997).

\section{Theoretical Framework}

Theoretical framework is defined as "the structure that can hold or support a theory of a research study [and] ...... introduces and describes the theory that explains why the research problem under study exists" (Abend, 2013 P.173). Three theories were considered relevant for this study, namely include Critical thinking and problem-solving model, Piagetian theory and The Activity system model

\subsection{Critical Thinking and Problem-Solving Model}

The critical thinking and problem-solving model, provides a comprehensive critical thinking model that allow students, including accountancy students, to reflect, analyse, memorise, and understand a given problem in any scenario (Rodzalan \& Saat 2015). The critical thinking and problem-solving model, guides accountancy students to think, reflect, understand, evaluate, and analyse basic and complex problems in learning environments. The critical thinking and problem-solving model is shown in Figure 1. 


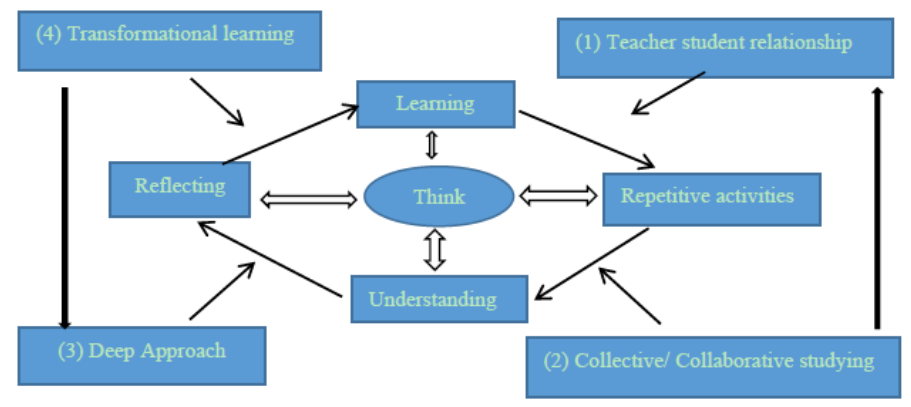

Figure 1. Critical thinking and problem-solving model

Source: Rodzalan and Saat (2015)

Accountancy students are required to think. Critical thinking is a higher-order type of thinking that is required to solve complex tasks or problems. Figure 1 shows that thinking happens at different stages in the learning process for students. According to Rodzalan and Saat (2015), at the reflecting stage, students are expected to think critically (higher-order thinking) which would lead them to repetitive activities or memorising a given task which would deepen their understanding. Each component is centred on thinking, because thinking enables clear analysis, reflecting, memorising, and understanding in the learning process. Applying repetitive activities, understanding, memorising, and reflecting will enable students to deliver sound learning with quality outcomes that improve problem-solving skills (Rodzalan \& Saat 2018). It builds lecturer or teacher-student relationships, which deepens collaboration among student(s) and teacher(s) (lecturers) with a deep learning approach. Transformative learning then makes for improved learning outcomes.

Lecturers are the fundamental role players in learning environments and training students to be critical thinkers. Rodzalan and Saat (2015) believed that the process of repeating activities or memorising them will promote understanding through collective or collaborative learning (studying). Through collaborative studying, students gain practical or experiential understanding of accounting problems. Cognitive theories can assist accountancy students to think critically. This model is suitable for addressing critical thinking among accountancy students and addressing accounting problems.

\subsection{Piagetian Theory}

This is an intellectual development stage that every human goes through, as recognised by the Swiss psychologist called Piaget (Lunenburg 2012). Piagetian theory involves abstract thinking in order to understand concepts and complexity throughout the learning process. There are four cognitive development stages every student will undergo as they reach academic maturity. Every student will not possess the same cognitive developmental stage at any given time, but they will all go through the developmental process. The stages are as follows:

Sensory motor stage: This is a stage which begins at birth and lasts until the age of two. This stage equips students to think into learning the basis of time, space, intentionality and causality (Lunenburg 2012).

Preoperational stage: This is a stage of language learning which happens between the ages of two and six. Here a child learns the basis of labelling of words and expression of feelings through language. They also learn through a trial and error principle which builds experiences and later purposeful judgements are made (Lunenburg 2012). Single worldviews are built, which will later expand to an understanding of things from others' viewpoints. Accounting learning knowledge is built through this process, namely basic principles of accounting from a personal viewpoint to a more complex one. Accountancy students' learning processes should include the repetition of tasks and activities to gain a deeper understanding of content.

Concrete operational stage: This development takes place between seven to nine years. The stage allows a child to conceptualise ideas to suit their personal skills and understanding. It enables a child to manage seen problems and understand the consequences (Lunenburg 2012). An accounting student who has watched accounting videos, problem stimulations, and pictures, will be in a better position to understand and interpret concepts by listening to a lecturer demonstrate. 
Formal operational stage: This stage takes place between 12 to 16 years. At this stage, a child can think alternatively and hypothetically, as well as come up with possible logical conclusions (Lunenburg 2012). At this stage, students can engage in more organised thinking, classifying, logical thinking, implication, and identification.

\subsection{Activity Theory}

Activity theory was rooted in the work of the great German philosopher Vygotsky of 1978 and a Russian psychologist in 1981, and it has become a well-used theoretical framework across disciplines (Hite \& Thompson 2019). Activity theory guides students towards understanding the relationship between a subject (an individual), an object (activity goal), and the tools used by the subject in achieving the object (Hite \& Thompson 2019).

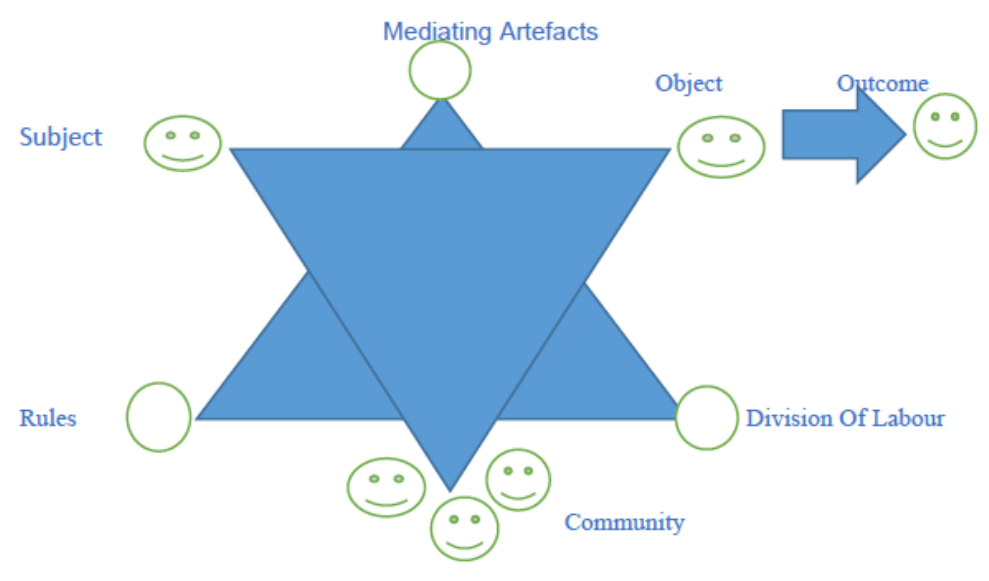

Figure 2 . The activity system model

Source: Hite and Thompson (2019)

Activity theory provides a platform for discussing team collaboration, team learning, and the construction of knowledge and idea. Activity theory is used to describe human interaction, activities in various disciplines like education, economics and management science, healthcare, and the human computer (Hite \& Thompson 2019). Activity theory can be used to describe the collaboration between lecturers and students towards building critical thinking. Learning accounting demands collaboration in tackling complex questions in different modules. Hence, activity theory guides students towards understanding the relationship between a subject, an object, and the tools used by the subject in achieving the object. It also enables an accountancy student to understand how to construct ideas in answering complex questions.

\section{Discussion}

\subsection{The Philosophical Approach to Critical Thinking}

The philosophical approach can be drawn back to the writings of Socrates, Plato, Aristotle, and more recently, Matthew Lipman and Richard Paul (Lai 2011). The writings demonstrate the philosophical approach of human thinking. The philosophical approach concentrates on the hypothetical critical thinker, and measures the possibilities and features of this person rather than the behaviours or actions that the critical thinker can perform (Lai 2011). Lai discusses critical thinking from the perspective of "perfections of thought". This preoccupation with the ideal critical thinker is evident in the American Philosophical Association's consensus portrait of the ideal critical thinker as someone who is inquisitive in nature, open-minded, flexible, fair-minded, has a desire to be well-informed, understands diverse viewpoints, and is willing to both suspend judgment and consider other perspectives (Lai 2011). Students are individuals who work within the philosophical custom environment to learn and apply knowledge through the principle of thoughts and reasoning. For example, Bailin (2002), regards critical thinking as thinking of a precise excellence to perfection, competence, standard, and accuracy. The principle of critical thinking prepared students to solve accounting challenges and problems in progressing toward perfection and being prepared for the industry. The psychological approach is different from the philosophical viewpoint in two ways: 1) it covers how people think and how they should think within a confirmed situation. 2) It deals with the actions of the critical thinker (Lai, 2011). 


\subsection{The Education Approach to Critical Thinking}

Critical thinking can be viewed and applied differently across various disciplines. The education discipline has a specific view about critical thinking with the underlining purpose of benefiting its students. The accounting discipline also perceived critical thinking in its own way for improved teaching and learning in addressing complex and practical accounting problems and challenges. Academic lecturers are challenged in terms of how to develop the capacity for students to think critically (Cascini \& Rich 2007). The three highest levels of constant principles used in critical thinking which has supported Bloom's taxonomy are analysis, synthesis, and evaluation. These three principles are fundamental in applying critical thinking in addressing accounting problems. For example, any student who is confronted with an accounting challenge will analyse the question as understanding what the question is. A proper synthesis must be performed in examining the level of the task that is to be performed. Evaluation is also necessary, as it will help in finding ways to tackle the challenge.

Despite the differences amongst the three schools of thought and their approaches to defining critical thinking, there are areas of agreement. First, researchers of critical thinking typically agree on the specific abilities encompassed by the definition, which include;

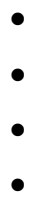

Analysing arguments, claims, or evidence,

Making inferences using inductive or deductive reasoning,

Judging or evaluating, and

Making decisions or solving problems.

Other abilities or behaviours recognised as significant to critical thinking include asking and answering questions for clarifications; identifying assumptions; interpreting and explaining; reasoning verbally, especially in relation to concepts of likelihood and uncertainty; predicting; and seeing both sides of an issue.

\subsection{Way(s) Students Are Able to Apply Critical Thinking in Solving Problems in an Accountancy Module}

Accounting educators have continually been called upon to develop intellectual skills that involve critical thinking and analysis (Cobb 2016). It is very important for accountancy students and future accountants to be empowered with critical thinking skills so they can solve complex problems and provide decisive conclusions (Reinstein \& Bayou 1997). Critical thinking is essential for accounting education, business education, and careers in general (Sergeant \& Cannon 2016). Accountancy students are expected to have critical thinking skills (Thompson \& Washington, 2015) to excel in their profession. According to Quitadamo and Kurtz (2007), there is a known benefit of critical thinking in academic and personal life which involves better academic grades and the daily application of reasoning.

The effective application of critical thinking relies first on a student's active participation in the learning process. Learning involves active learner participation in the active learning process. Accountancy students' (learners') ability to learn goes hand-in-hand with their active involvement to learn and apply what has been learned through critical thinking and analysis. Critical thinking skills involve assessing, analysing, and modifying ideas through what has been learned in the lecture room (Saputra et al. 2018). This approach to critical thinking brings the researcher back to the activity theory, which provides the platform for discussing team collaboration, team learning, construction of knowledge, and ideas in a learning environment. Active learning transfers the learning process from teachers (lecturers) to students (learners). It focuses on delivering what the students should learn using the available learning materials through active involvement in the process (Sava 2016). Active learning can be regarded as the $21^{\text {st }}$ century learning method with the idea of making learning more practical and engaging. According to Young and Warren (2011), active learning environments can foster engagement and participation from students.

Accounting knowledge should go beyond the classroom to more practical real-life examples. Critical thinking encourages deeper thinking processes in solving a problems or challenges from start to finish. According to Saputra et al. (2018), critical thinking and problem-solving skills are essential for the $21^{\text {st }}$ survival of anyone, including accountancy students. For critical thinking to be real and effective, active participation in the learning process is necessary. Active learning provides students with the opportunities, in a critical thinking situation and within their learning space, to listen, think, read, write, and meditate on the content, as well as to construct ideas and provide answers or solutions. According to Sava (2016), active learning prepares students to listen, write, read, and reflect on the learning content and much more.

Students' application of critical thinking can come in different ways also. Accountancy students can apply lively learning methods using the cube method. The cube method allows students to use six steps like describe, compare, 
associate, analyse, apply, and argue to address or tackle accounting questions and challenges (Sava 2016). He also offered the following six steps for solving real accounting questions, in this case those involving balance sheets:

1. Describe: in a real-life circumstance, students display or define how a balance sheet can be organised and prepared using materials like some textbooks, notebooks and others.

2. Compare: similarities are set, and comparisons are made between the financial statement part and other components of the balance sheet. They organise the sheet in the right format.

3. Associate: the principle of association allows students to show information on the correct balance sheet format.

4. Analyse: analyse all content in the balance sheets.

5. Apply: complete the balance sheet information, drawing inference from present knowledge about financial tasks.

6. Argument: assess the contents and define the accuracy of the answers provided.

Active learning promotes an environment which allows students to share ideas, collaborate, and rapidly respond to challenges.

The place of critical thinking has been deliberated and addressed by academics in journals, textbooks, workshops, conferences, and much more. However, accounting educators must be able to incorporate critical thinking into their teaching curriculum. Achieving critical thinking in an accounting curriculum is conceivable through addressing the following issues:

1. What is critical thinking and which aspect is vital for accountancy students and their profession?

2. How can critical thinking be presented to accounting university students?

3. How can critical thinking be taught to university accountancy students?

4. How can university accountancy students use critical thinking in solving accounting problems?

5. What are the barriers in the integration of critical thinking with the accounting curriculum and profession?

The above questions are vital in applying critical thinking to the accounting curriculum in an effort to address this complex task. However, there are some obstacles to integrating critical thinking into a curriculum. According to Sergeant and Cannon (2016), critical thinking skills are actually not well taught in academic institutions. Here are some of the challenges according to Reinstein and Bayou (1997):

1. Redundancy: Repetition of critical thinking ideas and concepts in various courses will eventually result in confusion and misunderstanding by students. Different courses or modules across various departments and faculties understand and apply critical thinking differently. Students, especially those in "Introduction to Accounting" may receive lectures in different departments which may practice critical thinking differently. Students may be confused in understanding and applying critical thinking in this instance.

2. Lack of critical thinking by educators: Teaching critical thinking should be done using basic concepts and demonstration that will empower students to understand and assimilate the components of critical thinking. Inversely, this approach is impractical for many accounting lecturers because they were not trained to achieve such.

3. Backward integration: Writing, reading, and analysis improves accounting procedures and the profession. These are backward addition principles that inspire critical thinking in the accounting profession and education. However, the teaching process of these concepts are missing in practice and in the accounting curriculum.

\subsection{Challenges Faced by Accountancy Students in Applying Critical Thinking in Solving Accounting Questions}

Learning takes place when students attain new knowledge and transform existing knowledge and skills into their own understanding and actions. Meaningful learning results in a long-lasting change in one's ability to do something or solve problems as a result of practice or experience (Cobb, 2016). Higher education (HE) in accounting is confronted with the challenge to shift its emphasis from reproducing technical knowledge to developing personal capabilities, such as critical thinking, creative thinking, problem solving, communication, and teamwork. Academics are challenged to develop the capacity of training students to be critical thinkers (Sergeant \& Cannon 2016). Students will not make the rational effort to improve their personal competence unless they first experience a deep attitude to learning and experience high-level conception of learning as well as have an intrinsic motivation to engage in deep learning in the context of a university accounting course as suggested by the educational psychology literature (Turner 2011). 
Students' attitudes and strategies are not the real problem for accounting education. The real issue is the extent to which preferences and associated (learning) strategies are challenged and modified by teaching and assessment strategies which students encounter (Turner 2011). Colleges and universities have recognized developing the critical thinking skills needed for success beyond the classroom as a primary goal of (Nold 2017).

Cobb (2016) proposes that effective critical thinking is a focused, rational and goal-directed effort of evaluating one's own thinking process. Critical thinking must demonstrate "the ability to present well-reasoned arguments and to evaluate correctly the arguments others present" (Cobb 2016). The intention of this paper is to confirm whether this is true, and if so, how accountancy students can be supported to change the ways they experience learning (Turner 2011). Giving accountancy students the backing they need to be able to transform the ways they experience how they learn accounting in a university accounting course, is necessary for the improvement of their personal capabilities, which they need to engage with business reality (the 'signified') and make commercial judgements, instead of just focusing on accounting numbers (the 'signs') (Turner 2011).

Such a change in the ways students experience learning can open up a new world of learning for accountancy students, and a world of new possibilities allowing and supporting them to grow personal abilities in areas such as critical thinking, creative thinking, problem-solving, communication, and teamwork (Turner 2011). These capabilities are necessary for accountancy students to improve their ability to make the commercial judgments required of accounting professionals, and indeed, are relevant and valuable for all aspects of students' lives. There is a need to develop the personal capabilities of accountancy students and support them in developing their personal capabilities, rather than simply supporting students to reproduce technical professional accounting rules (Turner 2011). The educational psychology literature and the education literature more generally suggest that students need to be supported to change these aspects of how they experience learning accounting before interventions designed to support the development of personal capabilities will be effective.

\subsection{High Levels of Surface Learning}

Critical thinking is a function of quality hard work, homework and peer interaction in the accounting discipline (Thompson \& Washington 2015). There is evidence that accountancy students may be more likely than students in arts, education and science to experience a surface approach to learning (Turner 2011). Although there is evidence of the widespread experience of surface learning by tertiary students across a range of disciplines, there is evidence that accountancy students can be expected to experience even higher levels of surface learning than students in other disciplines. It may be more challenging to support accountancy students to experience change in their approach to learning, than students in other disciplines. Insights gained from supporting accountancy students in experiencing deep learning may be valuable across the tertiary sector. However, in order to develop high level of learning, the following steps must be applied (Thompson \& Washington 2015):

1) Learning using objective(s).

2) Use questions while learning.

3) A lot of practical before summative and formative assessments.

4) Practice, review, reflect, refine, apply, and improve.

5) Give feedback.

\subsection{Studying Accounting Can Support Surface Learning}

There are some indications that learning accounting can provide or inspire students to have the knowledge of surface learning. There is proof that accountancy students' surface methods to learning increase and deep approaches to learning decrease in their first year at the university as an outcome of studying accounting (Turner 2011). The tendency to view the learning of accounting as involving rote memorization, which is confirmed by traditional teaching methods and large amounts of heavy content-oriented work, leads to learning behaviours that are unpredictable with the development of generic skills. As accountancy students make progress in their studies, they are less inclined to use deep processing approaches. This suggests that conventional accounting education actually promotes learning style preferences that are antithetical to the development of generic skills. There may be a combination of factors in the relationship between accountancy students and their learning context in university accounting courses, which may encourage them to experience surface learning. 


\section{Strategies That Can Be Used by the Lecturers to Ensure That Accountancy Students Are Able to Apply Critical Thinking in Solving Accounting Problems}

Critical thinking skills are fundamental for students to excel. The question remains, how are the lecturers inculcating critical thinking skills in accountancy students in solving accounting problems? The answer to this question will lead to a better understanding on the strategies used by lecturers to ensure that accountancy students are equipped with critical thinking skills in addressing accounting problems. There are different strategies used by lecturers to impact critical thinking skills on accountancy students in solving accounting problems, including the following:

Purposeful, reason and goal-oriented: The ability for accountancy students to excel in solving accounting problems, lies in being purposeful in reasoning and being goal-directed. Lecturers are able to push students to be purposeful in mind when confronted with complex accounting problems; they should reason critically on the same issue and be goal-oriented in thinking. These three keywords are used to motivate students and prepare them for addressing accounting problems.

Formulate inferences and calculate: Student's ability to solve accounting problems rely on their capability to formulate inferences from existing solution and examples, including the ability to calculate instantly with or without calculator. Calculating mind-set in making decisions pushes one to make inferences.

Analytical skills: according to Wilkin (2017), analytical skills allow students to envisage and assess other options in carrying out analysis. It includes the performance of logic analysis in breaking complex problems into smaller units for easy analysis. Accountancy students can apply these skills in dealing with complex accounting problems by breaking them down into smaller components.

Problem solving: It is an approach employed by lecturers to teach critical thinking so they can reason deeply (Wilkin 2017). Solving complex accounting problems requires students to be motivated in applying existing knowledge to a new challenge through proper evaluation, analysis, investigation, and reasoning (Wilkin 2017). In solving real-world problems, according to Aman et al. (2012), integrated case study (ICS) can be used, because it empowers accountancy students to solve problems in the industry.

Scaffolding: Lecturers use scaffolding to ensure that "students learn how and why" (Wilkin 2017) to complete accounting tasks. Scaffolding directs and support students and challenges them to formulate new knowledge in a given situation.

Problem-based assessment task: Problem-based assessment can be traced to problem-based learning (PBL) which allow students to learn using experiences to solve common to complex problems, allowing them to construct their learning knowledge. PBL has been used and applied in different disciplines like medicine, engineering, and law, and little is known about how it applies to accounting (Stanley \& Marsden, 2012). Problem-based assessment tasks give the student the opportunity to address current problems, using existing experience to tackle accounting problems in class as well as in a real-work environment.

Bloom's taxonomy: Bloom's taxonomy has been used in education for decades now with a great impact on the system in guiding the teaching and learning process. Bloom's taxonomy enables educators to understand students' learning demands and cater for different learners. From the beginning, Bloom's taxonomy has consisted of six levels, namely: knowledge, comprehensive, application, analysis, synthesis, and evaluation. The first three are lower-thinking order skills while the last three represent the higher-thinking order skills (Sergeant \& Cannon 2016). Sergeant and Cannon (2016) further believe that critical thinking can be well organised into three pillars, namely critical thinking disposition, application of higher-thinking order skills of Bloom's taxonomy, and the ability to use a strategic problem-solving process.

Teaching tools: Teaching the current generation of students will require the application of interactive teaching tools, which will allow the students to interact with each other while studying. According to Jayaprakash (2005), the use of group work, gamification (games), simulations and case studies can be suitable strategies in delivering interactive learning to students in the present century. These tools can be used in accounting classes to build critical thinking skills, which will help students solve complex accounting problems in and out of the classroom.

\section{Contribution of the Study}

Presently, academics are demanded to facilitate and guide students, while students are expected to develop accounting skills that will enable them to be self-directed and seek information (Jayaprakash 2005). Accounting by its nature demands deeper articulation, creativity, innovative thinking and critical thinking skills for any student to excel (Thompson \& Washington, 2015). Any kind of teaching method that fails to capture these kinds of skills will 
only produce undesirable results. The accounting discipline aims to solve financial and accounting problems and challenges. Students are expected to be articulate and critical thinking minded. A lack of creativity, and innovative and critical thinking will lead to students having difficulties in solving accounting problems. Accounting graduates are required to have a wide range of skills in the discipline (Barac \& du Plessis 2014). Achieving this involves applying the learning theory which will allow students to be empowered using real-work content and experiences in tackling complex problems (Jayaprakash 2005).

Achieving a wide range of skills in the accounting profession means there needs to be a change in teaching methods which universities have embraced (Barac \& du Plessis 2014). Critical thinking is an important attribute in higher institutions to achieve quality teaching and learning and also produce high calibre graduates (Moeti et al. 2017). The ability of the student to think critically drives academic success, which in return produces good graduate attributes. Higher institution graduates are required to acquire skills which will allow them to be fit for the work environment. Most of the time, however, graduates lack these skills when they graduate from universities (Moeti et al. 2017; Fahim \& Eslamdoost 2014). According to Wilkin (2017), critical thinking is a very important attribute for graduates.

\section{Conclusion}

In summary, this literature study has reviewed the ways in which undergraduate accountancy students can apply critical thinking in solving problems in their modules. An introduction and background to the study was highlighted. The study employed a systematic literature review, which aided in reviewing literatures relating to the theory used in the study, an overview of critical thinking in relation to accountancy students, the necessity for critical thinking, and ways students can apply critical thinking in answering questions. The study also highlighted verbs that should be well understood by students when answering accountancy questions. These include words like describe, compare, associate, analyse, apply, and argument.

Pressures to cultivate critical skills demanded by a 21 st century workplace justified different strategies used by lecturers in the accounting curriculum. Even though accountancy students encounter challenges in applying critical thinking in solving problems, it remains certain that accountancy academics can also help students engage in proper critical thinking by using appropriate teaching methods to ensure that accountancy students understand the content taught in class. The ability to think critically and the courage to use this skill are two of the most important attributes that a lecturer can bestow on students. Roush \& Smith (1997) said faculty curriculum coordinators should develop a more effective flow of subjects and perspectives in undergraduate programmes. Although it is impossible to deny the content of the accounting topics, the amount of content presented, and the presentation methods can clearly help students think critically. It is also seen that when accounting classrooms become enthralled with the associative catalyst of creative thinking, as well as the analytic blaze of critical thinking, thrilling learner-centred instruction will continue to shine.

This study was limited with empirical full reviewed research. It was also limited to accountancy programmes as the researchers are currently in the field of accountancy and accounting education. It is then recommended that future research endeavours can focus on identifying the variables in the review of literatures and measure conduct a longitudinal study that that involves human participants.

\section{Acknowledgement}

The authors would like to recognize the scientific committee in school of accounting at the North-West University for invaluable support and guidance in making this study a success.

\section{Competing Interests}

The authors confirm and declare that no personal or financial interest that might influence the study exist in writing up the article.

\section{Author Contributions}

LIN contextualized the article and was able to identify the research problem for the study through an in-depth review of literatures. H.V. co-authored the literature and made conceptual contributions.

\section{Funding Information}

This article did not receive any funding from any financial service corporation.

\section{Data Availability}

Literature sources are available for sharing and can also be found on any research search. 


\section{Disclaimer}

The opinions in this article are those of the authors, well conceptualized and sources used has been accurately referenced.

\section{References}

Abend, G. (2013). The meaning of theory: sociological theory 26. In R. A. Swanson (Ed.), Theory building in applied disciplines (pp. 173-199). San Francisco, CA: Berrett-Koehler Publishers.

Ali, R., Nori, W. N. W., \& Baharudin, I. (2019). Accounting Experiential Learning Firm (AELF): Learning accounting in an Office Setting. https://doi.org/10.18421/TEM82-50

Bailin, S. (2002). Critical thinking and science education. Science \& Education, 11(4), 361-375. Retrieved from https://link.springer.com/content/pdf/10.1023/A:1016042608621.pdf

Barac, K., \& Du Plessis, L. (2014). Teaching pervasive skills to South African accounting students. Southern African Business Review, 18(1), 53-79. https://doi.org/10.25159/1998-8125/5645

Bers, T. (2005). Assessing critical thinking in community colleges. New Directions for Community Colleges, 130 , 15-25. Retrieved from https://onlinelibrary.wiley.com/doi/pdf/10.1002/

Cascini, K., \& Rich, A. (2007). Developing critical thinking skills in the intermediate accounting class: using simulations with rubrics. Journal of Business Case Studies, 3(2), 17-28. https://doi.org/9371-1-10-20110705

Cobb, J. L. (2016). Critical and reflective thinking in an intermediate financial accounting course: an action research study. Texas: Christian University. Thesis - PhD. Retrieved from https://repository.tcu.edu/bitstream/handle/116099117/20628/Cobb_tcu_0229D_10843.pdf?isAllowed=y\&sequ ence $=1$

Fahim, M., \& Eslamdoost, S. (2014). Critical thinking: frameworks and models for teaching. English Language Teaching, 7(7), 141-151. https://doi.org/10.5539/elt.v7n7p141

Firdaus, F., Kailani, I., Bakar, M. N. B., \& Bakry, B. (2015). Developing critical thinking skills of students in mathematics learning. Journal of Education and Learning, 9(3), 226-236. Retrieved from https://core.ac.uk/download/pdf/193485436.pdf

Hite, R., \& Thompson, C. J. (2019). Activity theory as theoretical framework for analyzing and designing Global K-12 collaborations in engineering: A case study of a Thai-US elementary engineering project. Journal of International Engineering Education, 1(1), 1-39. $\quad$ Retrieved from https://digitalcommons.uri.edu/cgi/viewcontent.cgi?article=1005\&context=jiee

Jayaprakash, J. C. M. (2005). Strategies in teaching accounting in higher education. In the Reflective Practitioner: Proceedings of the 14th Annual Teaching Forums, 3-4 February. Perth: Murdoch University. Retrieved from https://clt.curtin.edu.au/events/conferences/tlf/tlf2005/refereed/jayaprakashj.html

Jenkins, E. K. (1998). The significant role of critical thinking in predicting auditing students' performance. Journal of Education for Business, 73(5), 274-279. https://doi.org/10.1080/08832329809601644

Kimmel, P. (1995). A framework for incorporating critical thinking into accounting education. Journal of Accounting Education, 13(3), 299-318. https://doi.org/10.1016/0748-5751(95)00012-B

Kurfiss, J. G. (1988). Research, practice and possibilities, ashe-eric higher education. Critical Thinking: Theory.

Lai, E. R. (2011). Critical thinking: A literature review. Pearson's Research Reports, 6, 40-41. Retrievedf from https://files.eric.ed.gov/fulltext/ED304041.pdf

Lunenburg, F. (2012). Teachers' use of theoretical frames for instructional planning: critical thinking, cognitive, and constructivist theories. International Journal of Scholarly Academic Intellectual Diversity, 14(1), 1-9. https://nationalforum.com/Electronic\%20Journal\%20Volumes/Lunenburg,\%20Fred\%20C.\%20Teachers\%20Us e\%20of\%20Theoretical\%20Frames\%20for\%

Maelah, R., \& Auzair, S. M. (2012). Implementation of integrated case studies course for accounting students. Procedia-Social and Behavioral Sciences, 59, 9-17. https://doi.org/10.1016/j.sbspro.2012.09.239

Moeti, B., Mgawi, R. K., \& Moalosi, W. T. S. (2017). Critical thinking among post-graduate diploma in education students in higher education: reality or fuss?. Journal of Education and Learning, 6(2), 13-24. https://doi.org/10.5539/jel.v6n2p13 
Mulnix, J. W. (2012). Thinking critically about critical thinking. Educational Philosophy and Theory, 44(5), 464-479. https://doi.org/10.1111/j.1469-5812.2010.00673.x

Nentl, N., \& Zietlow, R. (2008). Using Bloom's taxonomy to teach critical thinking skills to business students. College \& Undergraduate Libraries, 15(1-2), 159-172. https://doi.org/10.1080/10691310802177135

Nold, H. (2017). Using critical thinking teaching methods to increase student success: an action research project. International Journal of Teaching and Learning in Higher Education, 29(1), 17-32. Retrieved from http://www.isetl.org/ijtlhe/

Okoli, C., \& Schabram, K. (2010). A guide to conducting a systematic literature review of information systems research. Retrieved from http://sprouts.aisnet.org/10-26

Paré, G., \& Kitsiou, S. (2017). Methods for literature reviews. In Handbook of eHealth Evaluation: An Evidence-based Approach [Internet]. University of Victoria. Retrieved from https://www.ncbi.nlm.nih.gov/books/NBK481583/

Piper, R. J. (2013). How to write a systematic literature review: a guide for medical students. National AMR, Fostering Medical Research, 1-8. $\quad$ Retrieved from https://sites.cardiff.ac.uk/curesmed/files/2014/10/NSAMR-Systematic-Review.pdf

Quitadamo, I. J., \& Kurtz, M. J. (2007). Learning to improve: using writing to increase critical thinking performance in general education biology. CBE-Life Sciences Education, 6(2), 140-154. Retrieved from https://www.lifescied.org/doi/pdf/10.1187/cbe.06-11-0203.

Reinstein, A., \& Bayou, M. E. (1997). Critical thinking in accounting education: processes, skills and applications. Managerial Auditing Journal, 12(7), 336-342. https://doi.org/10.1187/cbe.06 -11-0203

Reinstein, A., \& Lander, G. H. (2008). Developing critical thinking in college programmes. Research in Higher Education Journal, $1, \quad 78 . \quad$ Retrieved $\quad$ from http://citeseerx.ist.psu.edu/viewdoc/download?doi=10.1.1.517.4671\&rep=rep1\&type=pdf

Rodzalan, S. A., \& Saat, M. M. (2015). The perception of critical thinking and problem-solving skill among Malaysian undergraduate students. Procedia-Social and Behavioral Sciences, 172, 725-732. https://doi.org/10.1016/j.sbspro.2015.01.425

Rodzalan, S.A., \& Saat, M.M., (2018). A mixed-method analysis on students' critical thinking and problem-solving skill development in Malaysian public universities. Journal of Physics: Conference Series, 1049, 012015. Retrieved from https://iopscience.iop.org/article/10.1088/1742-6596/1049/1/012015/pdf

Roush, M. L., \& Smith, G. S. (1997). Consultative teaching: International examples. Issues on Accounting Education, $\begin{array}{lr}12(1), & \text { Retrieved } \\ \text { https://www.researchgate.net/profile/G_Stevenson_Smith/publication/279914222 }\end{array}$

Saputra, M. D., Joyoatmojo, S., \& Wardani, D. K. (2018). The assessment of critical-thinking-skill tests for accounting students of vocational high schools. International Journal of Educational Research Review, 3(4), 85-96. Retrieved from https://pdfs.semanticscholar.org/36b4/a30c5e1b5ae24008569564a4c1ec0833857f.pdf

Sava, R. (2016). Using interactive methods in teaching accounting. Studies in Business and Economics, 11(2), 130-139. https://doi.org/10.1515/sbe-2016-0027

Sergeant, A., \& Camion, D. M. (2016). Critical thinking development through teaching: a sample project in accounting. Business Education Innovation Journal, 8(2). Retrieved from https://content.ebscohost.com/ContentServer.asp?

Sin, S., Jones, A., \& Wang, Z. (2015). Critical thinking in professional accounting practice: conceptions of employers and practitioners. In M. Davies, \& R. Barnett (Eds.), The palgrave handbook of critical thinking in higher education (pp. 431-456). New York: Palgrave Macmillan. Retrieved from https://www.researchgate.net/profile/Alan_Jones5/publication/304805947

Snyder, L. G., \& Snyder, M. J. (2008). Teaching critical thinking and problem-solving skills. The Journal of Research in Business Education, 50(2), 90. Retrieved from http://reforma.fen.uchile.cl

Stanley, T., \& Marsden, S. (2012). Problem-based learning: Does accounting education need it?. Journal of Accounting Education, 30(3-4), 267-289. https://doi.org/10.1016/j.jaccedu.2012.08.005

Taylor, B. (2004). Debating moral education - topic 3: teaching and learning. Centre for Academic Integrity conference. Duke University. 
Thompson, F., \& Washington, H. L. (2015). Critical thinking skills and teaching accounting: A comparative study. Journal of Finance and Accountancy, 19, 1. Retrieved from https://pdfs.semanticscholar.org.

Turner, M. C. (2011). The experience of deep learning by accounting students in a university accounting course. Thesis - PhD, Wellington: Victoria University.

Wilkin, C. L. (2017). Enhancing critical thinking: accounting students' perceptions. Education Training, 59(1), 15-30. https://doi.org//10.1108/ET-01-2015-0007

Willingham, D. T. (2008). Critical thinking: Why is it so hard to teach?. Arts Education Policy Review, 109(4), 21-32. https://doi.org/10.3200/AEPR.109.4.21-32

Young, M., \& Warren, D. L. (2011). Encouraging the development of critical thinking skills in the introductory accounting courses using the challenge problem approach. Issues in Accounting Education, 26(4), 859-881. https://doi.org/10.2308/iace-50065

\section{Copyrights}

Copyright for this article is retained by the author(s), with first publication rights granted to the journal.

This is an open-access article distributed under the terms and conditions of the Creative Commons Attribution license (http://creativecommons.org/licenses/by/4.0/). 